BIOKEMISTRI 19(2):59-64 (December 2007)

This article is downloadable online in PDF format at http://www.bioline.org.br/bk

Printed in Nigeria
An international journal published by the

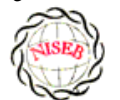

Origerian Society for \&xperimental ßiology

\title{
Some Biochemical and Haematological Studies on the Prevalence of Congenital Malaria in Ilorin, Nigeria
}

\section{Olatunji M. KOLAWOLE ${ }^{1 *}$, Abiodun G. JIMOH ${ }^{2}$, Samuel A. BABATUNDE ${ }^{3}$, Olayinka R. BALOGUN ${ }^{2}$, Ifeoma G. KANU ${ }^{1}$}

${ }^{1}$ Department of Microbiology, Faculty of Science, P.M.B. 1515, University of Ilorin, Ilorin, Nigeria.

${ }^{2}$ Department of Obstetrics and Gynaecology, P.M.B. 1515, University of Ilorin, Ilorin, Nigeria.

${ }^{3}$ Department of Haematology, P.M.B. 1515, University of Ilorin, Ilorin, Nigeria.

Received 12 November 2007

MS/No BKM/2007/049, @ 2007 Nigerian Society for Experimental Biology. All rights reserved.

\begin{abstract}
A seven month study (March-September 2006) on the prevalence of congenital malaria was carried out at the labour unit of three different hospitals within Ilorin metropolis: Eyitayo Hospital, Surulere Medical Hospital and Children Specialist Hospital Centre Gboro Ilorin. A total of 130 blood samples were collected from the mothers and their newborn babies and examined for malaria parasite using both thin and thick films. Maternal packed cell volume (PCV) and genotype was also determined using haematocrit method and cellulose acetate electrophoresis respectively. The prevalence rate of maternal, fetal, placental and cord parasitaemia were 37(28.46\%), 29(22.31\%), 33(25.38\%) and 30(23.08\%) respectively. Malaria infected maternal blood had a mild reduction in PCV level $(p<0.05)$. Genotype showed strong correlation with maternal, fetal, placental and cord parasitaemia $(p<0.05)$. However, the effect of malaria prophylaxis was shown to be more protective for the placental parasitaemia $(p<0.05)$. Finally maternal age and parity did not show strong correlation with Maternal, fetal, placental and cord parasitaemia $(p>0.05)$.
\end{abstract}

Keywords: Malaria; Mothers; Newborns

*To whom correspondence may be addressed. E-mail: tomak74@yahoo.com Tel: +234-8060088495 


\section{INTRODUCTION}

Congenital malaria is defined as malarial parasites demonstrated in the peripheral smear of the newborn within the first twenty four hours to seven days of life ${ }^{1}$. This results from malaria parasites crossing the placenta from maternal into the fetal circulation, although the mechanism of transplacental passage is obscure.

The localization of parasites within the placenta may jeopardize materno-foetal relationship, thus affecting the supply of nutrients to the foetus ${ }^{2}$. It has been postulated that pregnancy can make women more susceptible to malaria infection. This has been attributed to impairment of both humoral and cell mediated immunity as a result of pregnancy ${ }^{3}$.

Malaria in pregnancy is a common cause of severe maternal anaemia and these results from haemolysis of both parasitized and unparasitized red blood cells ${ }^{4}$. This is common in primigravidae compared to multigravidae.

This study was designed to determine the prevalence of congenital malaria at Ilorin, Kwara State using three hospitals: Eyitayo Hospital, Surulere Medical Centre and Children Specialist Hospital Centre Gboro. The first two represent private and the last public hospital respectively.

\section{MATERIALS AND METHODS}

\section{Study area}

The study was carried out at three different Hospitals; Eyitayo Hospital, Surulere Medical Centre and Children Specialist Hospital Centre Gboro, all in Ilorin, Kwara State over a period of seven months (March- September 2006).

\section{Subjects}

A hundred and thirty mothers and their babies delivered at the labour wards of these Hospitals were used after due parental and consultant consent.

\section{Parameters}

Questionnaire was applied to mothers and appropriate information filled such as maternal age, parity, past clinical history of malaria, anti malaria drug (such as chloroquine, amodiaquine in combination with sulphadoxinepyrimethamine) used for treatment and prophylaxis were obtained from them. Laboratory test such as packed cell volume (PCV) and haemoglobin genotype were carried out on the maternal blood samples while malaria parasite density estimations was done on both maternal and fetal and cord blood samples. Pregnant mothers presenting at the labour ward with history of fever were excluded from the study.

\section{Blood Collection}

Aseptic procedures were adopted in the collection of the blood samples. The placenta was washed with clean water immediately after delivery before the blood was collected. The cord was cleaned with 70 percent alcohol to avoid maternal blood contamination before it was dispensed into EDTA bottles. Fetal blood was obtained from a peripheral vein on the dorsum of the hand using a $23 \mathrm{G}$ needle. Venous maternal blood was obtained using $5 \mathrm{ml}$ syringe and dispensed into EDTA bottles.

\section{Preparation of Thick Blood Film}

Thick blood films for estimation of malaria parasite density were carried out according to the method of Greenwood and Armstrong ${ }^{5}$ described by Cheesbrough ${ }^{6}$. After appropriate staining and drying, slides were examined microscopically using the $\mathrm{x} 100$ (oil immersion) objectives.

\section{Procedure for estimation of malaria parasite density}

This was carried out using the thick blood film method of Greenwood and Armstrong. The average number of parasites counted per high power field (100 x objectives) was multiplied by 500. Between 10 and 15 fields were counted for each slide. The result is given per $\mu l$ of blood.

\section{Genotype Determination and packed cell volume Estimation}

The procedure for the determination of haemoglobin genotype and packed cell volume (PCV) of the subjects were carried out according to the methods described by Dacie and Lewis ${ }^{7}$. 


\section{Statistical Analysis}

The data generated in this study were analyzed using student's t -test for equality of means while Chi-square test was used to test for independence among the categorical variables at $\propto$ level of 0.05 (level of significance).

\section{RESULTS}

The prevalence rates of maternal, fetal, placental and cord parasitaemia were $37(28.46 \%)$, $29(22.31 \%), \quad 3(25.38 \%)$ and $30(23.08 \%)$ respectively (Table1). Maternal, fetal, placental and cord blood mean parasite density were $32450 \pm 128.46,12245 \pm 62.33,25660 \pm 110.70$ and $13355 \pm 65.06$ respectively (Table 2 ).

Table 1: Prevalence rates of malaria parasitaemia in maternal, fetal and placental cord blood.

\begin{tabular}{|l|l|l|l|}
\hline GROUP & $\begin{array}{l}\text { Positive } \\
\text { Parasitaemia } \\
(\%)\end{array}$ & $\begin{array}{l}\text { Negative } \\
\text { Parasitaemia } \\
(\%)\end{array}$ & Total (\%) \\
\hline Maternal & $\begin{array}{l}37 \\
(28.46 \%)\end{array}$ & $\begin{array}{l}93 \\
(71.54 \%)\end{array}$ & $\begin{array}{l}130 \\
(100 \%)\end{array}$ \\
\hline Fetal & $\begin{array}{l}29 \\
(22.31 \%)\end{array}$ & $\begin{array}{l}101(77.69 \\
\%)\end{array}$ & $\begin{array}{l}130 \\
(100 \%)\end{array}$ \\
\hline Placental & 33 & 97 & 130 \\
& $(25.38 \%)$ & $(74.62 \%)$ & $(100 \%)$ \\
\hline $\begin{array}{l}\text { Cord } \\
\text { blood }\end{array}$ & $\begin{array}{l}(23.08 \%) \\
(76.92 \%)\end{array}$ & $\begin{array}{l}130 \\
(100 \%)\end{array}$ \\
\hline
\end{tabular}

Table 2: Prevalence of malaria parasitaemia and parasite density in maternal, fetal, placental and cord blood

\begin{tabular}{|l|l|l|l|}
\hline $\begin{array}{l}\text { Nature of } \\
\text { sample }\end{array}$ & $\begin{array}{l}\text { No of } \\
\text { samples }\end{array}$ & $\begin{array}{l}\text { No of } \\
\text { positive } \\
\text { samples }\end{array}$ & $\begin{array}{l}\text { Mean parasite } \\
\text { density }(\mu \mathrm{l})\end{array}$ \\
\hline $\begin{array}{l}\text { Maternal } \\
\text { blood }\end{array}$ & 130 & $37(28.46 \%)$ & $32450 \pm 128.46$ \\
\hline Fetal blood & 130 & $29(22.31 \%)$ & $12245 \pm 62.33$ \\
\hline $\begin{array}{l}\text { Placental } \\
\text { blood }\end{array}$ & 130 & $33(25.38 \%)$ & $25660 \pm 110.70$ \\
\hline Cord blood & 130 & $30(23.08 \%)$ & $13355 \pm 65.06$ \\
\hline
\end{tabular}

Mean maternal PCV was $32.81 \pm 0.42$, those with parasitaemia were $30.86 \pm 3.56$ and those without parasitaemia were $33.58 \pm 5.00$ (Table 3). Malaria infected maternal blood had a mild reduction in PCV level. Maternal PCV showed strong correlation with maternal parasitaemia $(p<0.05)$. With reference to Genotype in Table 4 , it was discovered that parasitaemia was higher in individual with haemoglobin genotype AA. This was followed by individual with haemoglobin genotype AS. Only one patient had haemoglobin genotype AC but showed negative parasitaemia except for the placenta, which showed positive parasitaemia. Genotype showed strong correlation with maternal, fetal, placental and cord parasitaemia $(p<0.05)$.

Most of the women who took malaria prophylaxis still showed evidence of malaria parasitaemia. Malaria prophylaxis did not seem to affect maternal parasitaemia but was shown to be more protective for the placental parasitization $(p>0.05)$ (Table 3).

Table 3: Mean values of maternal and fetal indices in all patients, those with positive and negative parasitaemia.

\begin{tabular}{|l|l|l|l|l|}
\hline $\begin{array}{l}\text { Variable } \\
\text { (means) }\end{array}$ & All patients & $\begin{array}{l}\text { Positive } \\
\text { parasitaemia }\end{array}$ & $\begin{array}{l}\text { Negative } \\
\text { parasitaemia }\end{array}$ & p-value \\
\hline $\begin{array}{l}\text { Maternal } \\
\text { Gestational } \\
\text { age }\end{array}$ & $2.11 \pm 0.05$ & $1.97 \pm 0.50$ & $2.16 \pm 0.56$ & 0.076 \\
\hline Parity & $1.63 \pm 0.04$ & $1.59 \pm 0.50$ & $1.65 \pm 0.48$ & 0.059 \\
\hline $\begin{array}{l}\text { Maternal } \\
\text { PCV }\end{array}$ & $32.81 \pm 0.42$ & $30.86 \pm 3.56$ & $33.58 \pm 5.00$ & 0.003 \\
\hline
\end{tabular}

The mean gestational age and parity of the patients were $2.11 \pm 0.05$ years and $1.63 \pm 0.04$ years respectively. The mean age of mothers with parasiteamia was $1.97 \pm 0.50$ years and those without parasitaemia were $2.16 \pm 0.56$ years (Table 3). Age group 14-20years had the highest prevalence of $38.5 \%$ maternal, $30.8 \%$ fetal, $30.8 \%$ placental and $30.8 \%$ cord parasitaemia which was closely followed by age group 2130years which had $31.1 \%, 24.4 \%, 27.8 \%, 25.6 \%$ maternal, fetal, placental and cord parasitaemia respectively while the lowest prevalence of $14.8 \%$ maternal, $11.1 \%$ fetal, $11.1 \%$ placental and $11.1 \%$ cord parasitaemia was seen in age group 31-40 years (Table 5). Maternal age showed no strong correlation with maternal, fetal, placental and cord parasitaemia $(p>0.05)$.The lowest parasitaemia was seen in age group 31-40 years (Table 5).

Mean parity of mothers with parasitaemia was $1.59 \pm 0.50$ and those without parasitaemia were $1.65 \pm 0.48$ (Table 3). Parasitaemia was higher in 
Table 4: Genotype and malaria prophylaxis in relation to maternal, fetal placental and cord parasitaemia

\begin{tabular}{|l|l|l|l|l|l|l|l|l|}
\hline & \multicolumn{2}{|c|}{ Maternal blood } & \multicolumn{2}{c|}{ Fetal blood } & \multicolumn{2}{c|}{ Placental blood } & \multicolumn{2}{c|}{ Cord blood } \\
\hline Genotype & $\begin{array}{l}\text { Positive } \\
(\%)\end{array}$ & $\begin{array}{l}\text { Negative } \\
(\%)\end{array}$ & $\begin{array}{l}\text { Positive } \\
(\%)\end{array}$ & $\begin{array}{l}\text { Negative } \\
(\%)\end{array}$ & $\begin{array}{l}\text { Positive } \\
(\%)\end{array}$ & $\begin{array}{l}\text { Negative } \\
(\%)\end{array}$ & $\begin{array}{l}\text { Positive } \\
(\%)\end{array}$ & $\begin{array}{l}\text { Negative } \\
(\%)\end{array}$ \\
\hline AA & $32(41.6 \%)$ & $45(58.4 \%)$ & $25(32.5 \%)$ & $52(.67 .5 \%)$ & $27(35.1 \%)$ & $50(64.9 \%)$ & $27(35.1 \%)$ & $50(64.9 \%)$ \\
\hline AS & $5(9.6 \%)$ & $47(90.4 \%)$ & $4(7.7)$ & $48(92.3 \%)$ & $47(9.6 \%)$ & $47(90.4 \%)$ & $3(5.8 \%)$ & $49(94.2 \%)$ \\
\hline AC & - & $1(100 \%)$ & - & $1(100 \%)$ & $1(100 \%)$ & - & - & $1(100 \%)$ \\
\hline P-value & $\mathrm{P}<0.05$ & & $\mathrm{P}<0.05$ & & $\mathrm{P}<0.05$ & & $\mathrm{P}<0.05$ & \\
\hline $\begin{array}{l}\text { Malaria } \\
\text { prophylaxis }\end{array}$ & & & & & & & & \\
\hline Yes & $14(38.9 \%)$ & $22(61.1 \%)$ & $13(36.1 \%)$ & $23(63.9 \%)$ & $11(30.6 \%)$ & $25(61.4 \%)$ & $12(32.4 \%)$ & $25(67.6 \%)$ \\
\hline No & $22(23.4 \%)$ & $72(76.6 \%)$ & $19(20.2 \%)$ & $75(79.8 \%)$ & $19(20.2 \%)$ & $75(79.8 \%)$ & $18(19.4 \%)$ & $75(80.6 \%)$ \\
\hline P-value & $\mathrm{P}>0.05$ & & $\mathrm{P}>0.05$ & & $\mathrm{P}<0.05$ & & $\mathrm{P}>0.05$ & \\
\hline
\end{tabular}

$P>0.05$ showed no strong correlation

$P<0.05$ showed strong correlation

Table 5: Maternal age and parity in relation to maternal, fetal, placental and cord parasitaemia

\begin{tabular}{|l|l|l|l|l|l|l|l|l|}
\hline & \multicolumn{2}{|l|}{ Maternal blood } & \multicolumn{2}{l|}{ Fetal blood } & \multicolumn{2}{l|}{ Placental blood } & \multicolumn{2}{l|}{ Cord blood } \\
\hline $\begin{array}{l}\text { Age } \\
(\text { years })\end{array}$ & $\begin{array}{l}\text { Positive } \\
(\%)\end{array}$ & $\begin{array}{l}\text { Negative } \\
(\%)\end{array}$ & $\begin{array}{l}\text { Positive } \\
(\%)\end{array}$ & $\begin{array}{l}\text { Negative } \\
(\%)\end{array}$ & $\begin{array}{l}\text { Positive } \\
(\%)\end{array}$ & $\begin{array}{l}\text { Negative } \\
(\%)\end{array}$ & $\begin{array}{l}\text { Positive } \\
(\%)\end{array}$ & $\begin{array}{l}\text { Negative } \\
(\%)\end{array}$ \\
\hline $14-20$ & $5(38.5 \%)$ & $8(61.5 \%)$ & $4(30.8 \%)$ & $9(69.2 \%)$ & $4(30.8 \%)$ & $9(69.2 \%)$ & $4(30.8 \%)$ & $9(69.2 \%)$ \\
\hline $21-30$ & $28(31.1 \%)$ & $62(68.9 \%)$ & $22(24.4 \%)$ & $68(75.6 \%)$ & $25(27.8 \%)$ & $65(72.2 \%)$ & $23(25.6 \%)$ & $67(74.4 \%)$ \\
\hline $31-40$ & $4(14.8 \%)$ & $23(85.2 \%)$ & $3(11.1 \%)$ & $24(88.9 \%)$ & $3(11.1 \%)$ & $24(88.9 \%)$ & $3(11.1 \%)$ & $24(88.9 \%)$ \\
\hline P-value & $\mathrm{P}>0.05$ & & $\mathrm{P}>0.05$ & & $\mathrm{P}>0.05$ & & $\mathrm{P}>0.05$ & \\
\hline Parity & & & & & & & & \\
\hline Primigravidae & $15(31.3 \%)$ & $33(68.7 \%)$ & $11(22.9 \%)$ & $37(77.1 \%)$ & $11(22.9 \%)$ & $37(77.1 \%)$ & $12(25.0 \%)$ & $36(75.0 \%)$ \\
\hline Multigravidae & $22(26.8 \%)$ & $60(73.2 \%)$ & $18(22.0 \%)$ & $64(78.0 \%)$ & $22(26.8 \%)$ & $60(73.2 \%)$ & $18(22.0 \%)$ & $64(78.0 \%)$ \\
\hline P-value & $\mathrm{P}>0.05$ & & $\mathrm{P}>0.05$ & & $\mathrm{P}>0.05$ & & $\mathrm{P}>0.05$ & \\
\hline
\end{tabular}

$P>0.05$ showed no strong correlation

primigravidae (Table 5). Maternal age and parity showed no strong correlation with maternal, fetal, placental and cord parasitaemia $(p>0.05)$

\section{DISCUSSION}

Congenital malaria is defined as malarial parasites demonstrated in the peripheral smear of the newborn within the first twenty four hours to seven days of life ${ }^{1}$. Congenital malaria hitherto thought to be rare is becoming increasingly prevalent.

The prevalence rates of maternal, fetal, placental and cord parasitaemia recorded in this study were $28.4 \%, 22.31 \%, 25.38 \%$ and $23.08 \%$ respectively (Table 1). In Maputo, Mozambique $17.3 \%$ of screened mothers were infected and so was $1.5 \%$ of their newborn babies [8]. In the highlands of Jos, northern Nigeria, $44.51 \%$ of mothers and $28.2 \%$ of their newborn were infected ${ }^{9}$. Higher prevalence of congenital malaria in some other communities in Nigeria have been reported as in references 4, 10, 11 and 12 which were $32 \%, 55 \%, 26.61 \%$ and $46.7 \%$ respectively. However, this present study has also established that congenital malaria is a common occurrence amongst the newborns in Ilorin, Kwara State, Nigeria

The mean parasitaemia density in maternal, placental, fetal and cord blood were $32450 \pm$ $128.46,12245 \pm 62.33,25660 \pm 110.70$ and $13355 \pm 65.06$ respectively (Table 2). The highest parasite density was seen in maternal blood while the least was seen in fetal blood. The low prevalence rate of parasite density in fetal blood could be as a result of barrier offered by the placental to the foetus. This in agreement with the finding of Ezechukwu et al ${ }^{1}$.

Maternal PCV had a strong correlation with maternal parasitaemia at $p<0.05$ (Table 3). The significant reduction in PCV level indicates a 
relationship between malaria parasitaemia and anaemia. This may be due to the fact that pregnant women with malaria parasitaemia are likely to be anemic though may or may not be severe. This is in line with the report of Chimsuku et $a l^{13}$.

Women with haemoglobin genotype AA showed high prevalence of parasitaemia with about $41.6 \%$ as compared with $5 \%$ recorded in haemoglobin genotype AS women (Table 4). This is in accordance with the findings of Cheesbrough $^{6}$ who reported that sickle cell trait carriers have lower parasite densities and are more protected against death from severe malaria and the development of hyper reactive malaria splenomegaly compared with haemoglobin genotype AA (HbAA) and haemoglobin genotype SS (HbSS) individuals. Genotype showed strong correlation with maternal, fetal, placental and cord parasitaemia $(p<0.05)$. However, malaria prophylaxis was shown to be more protective for the placental parasitization only (Table 4). This disagrees with Jimoh $^{14}$ who reported that malaria prophylaxis was more protective for the placental parasitization and fetal parasitaemia.

Furthermore, it was discovered that age group 14-20 and 21-30 years were more susceptible than older ones (Table 5). This confirmed that as women get older, their resistance to malaria becomes higher due to improvement in host immunity. This is in consonance with the work of McGregor ${ }^{15}$ who reported a decline in malaria prevalence as age increase and that with improved host immunity thus reducing susceptibility in later years.

Finally, prevalence of malaria parasitaemia was higher in primigravidae compared to multigravidae (Table 5). This could be as a result of immunosuppresant action of hormone notably cortisone on cell mediated immunity produced regularly during pregnancy by primigravidae. This is in accordance with the work of Egwunyanga et al ${ }^{9}$.

Therefore in order to reduce the incidence of congenitally acquired malaria, the need for adequate antenatal care geared towards providing early diagnosis and prompt treatment of malaria should be practiced. There is need for Government at all levels to provide should distribute antimalaria drugs free of charge to all pregnant women.

In Conclusion, pregnant women should be encouraged to register for antenatal care early and they should be placed on malaria prophylaxis immediately.

\section{REFERENCES}

1. Ezechukwu, C.C Ekejindu, I.M., Ugocchukwu, E.F., Egbuonu, I., Oguatu, M. and Chuwuka, J.O. (2004) Congenitally Acquired Malaria in a hyperendemic Area: A cohort study. Tropical Journal of Medical Science Research 8:44-47.

2. Uko, E.K., Emeribe, A.O., Ejezie, G.C. (1999) Maternal and Cord Hemoglobin concentration in relation to malaria infection in Calabar. Nigerian Journal of Medicine. 8:27-29.

3. Okonofua, F., Adeniran, M., Adetugbo, D. and Nganwuchu, A. (1990) Women attending antenatal clinic of the Obafemi Awolowo University Teaching Hospital, IleIfe Nigeria. Medicare 25:8-11.

4. Jimoh, A.A.G. (2004) Materno -fetal Haematological. Relationship in malaria at Mongomo, Equatorial Guinea. African Journal of Clinical and Experimental Microbiology 5: 217-219.

5. Greenwood, B. M. and Armstrong J. R. M. (1991) Comparison of two single methods for determining malaria parasite density. Transactions Royal Society typical medicine and Hygiene 85:186-188.

6. Cheesbrough, M. (2005) District Laboratory Practice in Tropical Countries. $2^{\text {nd }}$ Edition.Cambridge University Press, United Kingdom.pp.244-251.

7. Dacie J.V. and Lewis S.M. (1991) Practical Haematology, $7^{\text {th }}$ Editor. London, Churchill Livingstone, pp 50-51; 244-245.

8. Bergstrom S.,Fernandes A., Schwaibach J. and Perez O., Miyar, R. (1993) Materno-fetal transmission of pregnancy malaria: an immuno- 
parasitologically study on 202 patients in Maputo. Gynecol. Obstet. Invest. 35:103107

9. Egwunyanga, O. A., Ajayi, J. A. Oluyinka, A. and Popoola D. D. (1995) Transplacental passage of Plasmodium faciparum and Seroevaluation of Newborns in Northern Nigeria. J. Commun. Dis. 27: 77- 83.

10. Mackay R. A. (1934) Note on congenital malaria. Tropical Disease Bulletin 31:427

11. Obiajunwa, J. A., Owa, O. and Adeodu, O. O. (2005) Prevalence of congenital Malaria in Ile-Ife Nigeria. Journal of Tropical Pediatrics. 51:1-3

12. Rienhardt, M. C., Ambroise-Thomas, P., Cavallo-Serra, R., Meylan, C. and Gautier, R. (1978) Malaria at Delivery in Abidjan. Helvetica Paediatrica Acta 33:6584
13 Chimsuku, L., Verhoeff, F. H., Maxwell, S. M., Brabin B. J. and Kazembe, P. (1994) Eleven more consequences of Malaria infection in pregnant women and their infants. Memoirs do Institute Oswaldo Cuz.89:1-2.

14 Jimoh, A.A.G. (2003) Epidemiological study of malarial parasites in pregnant Mothers, placenta and Newborns at Mongomo, Guinea Equatorial. Nigeria Clinical Review 3:24-27.

15 McGregor, I. A, Wilson, M. E. and Billewiez, W. Z. (1983) Malaria infection of the placental in the Gambia West Africa. Its incidence and relationship to still birth weight and placental weight. Transactions of the Royal Society of Tropical Medicine and Hygiene 77:232-24 